\title{
ON GENERALIZATIONS OF SOME
} CLASSICAL INTEGRAL INEQUALITIES

\section{ZHENG LIU}

Abstract. A unified treatment for generalizations of the midpoint, trapezoid, averaged midpointtrapezoid and Simpson type inequalities is obtained. Various error bounds for these generalizations are established. Mathematics subject classification (2010): 26D15.

Keywords and phrases: Midpoint type inequality, trapezoid type inequality, Simpson type inequality, averaged midpoint-trapezoid type inequality, absolutely continuous.

\section{REFERENCES}

[1] N. B. Barnett, S. S. Dragomir, A. Sofo, Better bounds for an inequality of the Ostrowski type with applications, Demonstratio Math. 34 (3) (2001), 533-542.

[2] P. CERONE AND S. S. DRAGOMIR, Midpoint type rules from an inequalities point of view, Handbook of Analytic-Computational Methods in Applied Mathematics, CRC Press N. Y. (2000), 135-200.

[3] P. Cerone AND S. S. Dragomir, Trapezoidal type rules from an inequalities point of view, Handbook of Analytic-Computational Methods in Applied Mathematics, CRC Press N. Y. (2000), 65-134.

[4] P. Cerone, S. S. Dragomir, J. Roumeliotis, Some Ostrowski type inequalities for $n$-time differentiable mappings and applications, Demonstratio Math. 32 (2) (1999), 697-712.

[5] S. S. Dragomir, R. P. Agarwal, P. Cerone, On Simpson's inequality and applications, J. Inequal. Appl. 5 (2000), 533-579.

[6] A. Guessab AND G. SChmeIsser, Sharp integral inequalities of the Hermite-Hadamard type, J. Approx. Theory 115 (2002), 260-288.

[7] Z. LIU, Refinement of an inequality of Grüss type for Riemann-Stieltjes integral, Soochow J. Math. 30 (4) (2004), 483-489.

[8] Z. LiU, An inequality of Simpson type, Proc R. Soc. A (2005), 461, 2155-2158.

[9] Z. LiU, More on inequalities of Simpson type, Acta Mathematica Academiae Paedagogicae Nyíregyháziensis 23 (2007), 15-22.

[10] Z. LiU, Note on a paper by N. Ujević, Appl. Math. Lett. 20 (2007), 659-663.

[11] Z. LiU, Some Ostrowski-Grüss type inequalities and appplications, Comput. Math. Appl. 53 (2007), 73-79.

[12] Z. LiU, A sharp L2 inequality of Ostrowski type, ANZIAM J. 49 (2008), 423-429.

[13] Z. LIU, Another sharp $L_{2}$ inequality of Ostrowski type, ANZIAM J. 50 (2008), 129-136.

[14] Z. LiU, More on the averaged midpoint-trapezoid type rules, Appl. Math. Comput. 218 (2011), 13891398.

[15] Z. LiU, Some sharp modified Simpson type inequalities and applications, Vietnam J. Math. 39: 2 (2011), 135-144.

[16] M. Matić, J. PeČArić, N. UjeviĆ, Improvement and further generalization of inequalities of Ostrowski-Grüss type, Comput. Math. Appl. 39 (2000), 161-175.

[17] K. L. Tseng, S. R. Hwang, S. S. Dragomir, Generalizations of weighted Ostrowski type inequalities for mappings of bounded variation and their applications, Comput. Math. Appl. 55 (2008), $1785-1793$.

[18] N. Ujević, Sharp inequalities of Simpson type and Ostrowski type, Comput. Math. Appl. 48 (2002), $145-151$. 